\title{
Union-Nonunion Differentials and Establishment Size: Evidence from the NLSY*
}

\author{
PHANINDRA V. WUNNAVA \\ Middlebury College, Middlebury, VT 05753 \\ BRADLEY T. EWING \\ Texas Tech University, Lubbock, TX 79409
}

We provide new empirical evidence on union-nonunion differentials using the 1990 wave of the National Longitudinal Surveys of Youth (NLSY) data set which allows us to examine a broader set of fringe benefits than most other studies and provides a rich set of control variables. Our major finding is that the union effect decreases with establishment size for both components of the compensation structure, i.e., wages and fringe benefits.

\section{Introduction}

Much has been written about the effects of employer size on earnings and the impact of unions on wages with the general consensus being that both lead to higher pay. For instance, Mellow (1982), Brown and Medoff (1989), Evans and Leighton (1989), Main and Reilly (1993), and Morisette (1993) suggest that larger firms pay higher wages. The union wage premium is also well documented. Jarrell and Stanley (1990) provide an extensive review of the literature and also perform a meta-analysis of the unionnonunion wage gap that supports this proposition. Podgursky's (1986) pioneering work investigated the impact of firm size on union-nonunion wage differentials and showed that union-nonunion wage differentials are largest in small plants.

Related research has studied the union-nonunion total compensation differential in terms of the industry output and labor market structures (Okunade et al., 1992) while Robinson (1991) examined the male-female gap in pension and health insurance benefits finding no evidence that benefits differentials offset earnings differentials. Even and Macpherson (1990) examined gender differences in pension coverage and the resulting wage gap using the Current Population Survey. In addition to finding that females were less likely to have a pension, they determined that women are paid more in the pension sector. Furthermore, Casey (1994) found that employees in establishments with fringe benefits received higher pay than those employed in firms without benefits. Finally, Wiatrowski (1994) documented the existence of union-nonunion differences in benefit provisions.

Given this vast literature on unions, firm size, and benefits, it is surprising that little research has explicitly addressed union-nonunion benefit differentials by establishment size. One such paper on this issue (Bramley et al., 1989) found that the pattern for health insurance coverage was similar to that found by Podgursky (1986) but that the 
largest differential in terms of pension coverage occurred in the smallest and largest plants (i.e., a U-shaped pattern). Our paper extends this research by examining a much broader set of fringe benefits. By using the National Longitudinal Surveys of Youth data set we exploit a rich set of explanatory variables and concentrate our attention on union-nonunion benefit differentials by establishment size on a much larger set of benefits than previously examined in most other studies.

\section{Establishment Size and Union-Nonunion Differential}

As described in Bramley et al. (1989), there are three theoretical explanations why the union-nonunion wage/benefit differential may vary by establishment size. First, large establishments may offer higher compensation than smaller firms to lessen the likelihood of unionization. The threat of unionization is greatest in larger nonunion firms which recognize that they are the best union targets since the large firm provides a larger worker pool than a small firm. The larger worker pool allows more workers to be solicited at a lower cost to the union organizers than at a small firm. There are economies of scale in union organization. Consequently, the large nonunion firm raises compensation in order to maintain worker satisfaction and discourage unionization (Podgursky, 1986). ${ }^{1}$ Even and Macpherson (1994) make a distinction between firm size and establishment size and contend that the former effects clearly dominate the effects of the latter. They attribute this pattern to the scale economies in the administration of fringe benefits that are likely related to firm size and not establishment size.

Second, efficiency-wage theory also provides a rationale for the existence of unionnonunion wage/benefit differentials by firm size. This theory provides several reasons why larger firms pay higher wages than smaller firms: to raise workers' effort level, reduce employee turnover, increase workers' loyalty to their employer, and to attract a better pool of workers from which to hire. Oi $(1983,1987,1990)$, focusing on the effect of wages on effort, suggests that employer size is one measure of monitoring technology. In particular, it is more difficult (costly) to detect shirking in larger firms, ceteris paribus. The recurring theme of the efficiency wage model is that a trade-off exists between wages and some measure of supervisory intensity (Lindberg and Snower, 1987).

Third, as pointed out in Bramley et. al. (1989), there appears to be a maximum wage for a particular job. This is because wage dispersion effects of unions presupposes the existence of a binding upper limit constraint on the wage for a particular job (Freeman and Medoff, 1982). In large nonunion firms the wage is often close to the maximum, but in smaller nonunion firms the wage is far below the maximum. When the large firm becomes unionized there will only be a small increase in wages so that the maximum is not surpassed; however, if the small firm becomes unionized the wage can increase a relatively large amount without reaching the maximum. Consequently, the same factors that lead to higher wages in larger firms also lead to larger unionnonunion wage differentials in small firms relative to large firms.

These arguments clearly predict larger union-nonunion benefit differentials should occur in small plants. However, given the finding by Bramley et al. (1989) of the 
U-shaped pattern with regards to pension coverage, it is unclear if that is an anomaly or if other benefits also follow a similar pattern. Moreover, by studying a number of benefits we may be able to discern how union strategies differ across establishment sizes when it comes to the distribution between wages and benefits.

\section{Data, Methodology, and Empirical Results}

The data are from the National Longitudinal Surveys of Youth (NLSY) which has interviewed respondents annually from 1979 to present. The initial wave contained 12,686 individuals between the ages of 14 and 21 . Our sample consists of males who worked for pay in the year prior to the 1990 wave in the nonagricultural, nonpublic sector. The study focused solely on males, partly to reduce the heterogeneity problem associated with lumping males and females together into the same sample. Following Bramley et al. (1989) we categorize workers as belonging to one of the following four employer establishment sizes: SIZEI (0 to 24 workers), SIZE2 (25 to 99 workers), SIZE3 (100 to 499 workers), and SIZE4 (500 or more workers). Workers are identified as being union or nonunion members. See Table 1 for selected variable definitions and descriptive statistics by establishment size.

Table 1

Selected Variable Definitions and Descriptive Statistics by Establishment Size

\begin{tabular}{|c|c|c|c|c|c|}
\hline Variable & Definition & $\begin{array}{l}S I Z E I \\
(0-24)\end{array}$ & $\begin{array}{c}S I Z E 2 \\
(25-99)\end{array}$ & $\begin{array}{c}\text { SIZE3 } \\
(100-499)\end{array}$ & $\begin{array}{l}\text { SIZE4 } \\
(500+)\end{array}$ \\
\hline UNION & $\begin{array}{l}\text { belongs } \\
\text { to union }\end{array}$ & $\begin{array}{c}0.0724 \\
(0.2593)\end{array}$ & $\begin{array}{c}13.41 \\
(0.3412)\end{array}$ & $\begin{array}{c}23.00 \\
(0.4214)\end{array}$ & $\begin{array}{c}21.15 \\
(0.4091)\end{array}$ \\
\hline$M E D I C A L$ & $\begin{array}{l}\text { medical/health } \\
\text { insurance }\end{array}$ & $\begin{array}{c}0.5748 \\
(0.4947)\end{array}$ & $\begin{array}{c}0.8337 \\
(0.3728)\end{array}$ & $\begin{array}{c}0.9271 \\
(0.2603)\end{array}$ & $\begin{array}{c}0.9647 \\
(0.1847)\end{array}$ \\
\hline RETIREMENT & $\begin{array}{l}\text { retirement plan } \\
\text { other than SEC }\end{array}$ & $\begin{array}{c}0.3123 \\
(0.4638)\end{array}$ & $\begin{array}{c}0.5900 \\
(0.4924)\end{array}$ & $\begin{array}{c}0.7857 \\
(0.4109)\end{array}$ & $\begin{array}{c}0.8929 \\
(0.3098)\end{array}$ \\
\hline LIFE INSURANCE & life insurance & $\begin{array}{c}0.4339 \\
(0.4959)\end{array}$ & $\begin{array}{c}0.7042 \\
(0.4569)\end{array}$ & $\begin{array}{c}0.8333 \\
(0.3732)\end{array}$ & $\begin{array}{c}0.9094 \\
(0.2875)\end{array}$ \\
\hline DENTAL & dental insurance & $\begin{array}{c}0.3280 \\
(0.4698)\end{array}$ & $\begin{array}{c}0.5569 \\
(0.4973)\end{array}$ & $\begin{array}{c}0.6990 \\
(0.4593)\end{array}$ & $\begin{array}{c}0.8553 \\
(0.3524)\end{array}$ \\
\hline $\ln W A G E$ & $\begin{array}{l}\text { natural log of } \\
\text { hourly wage } \\
\text { sample size }\end{array}$ & $\begin{array}{c}2.1882 \\
(0.5356) \\
760\end{array}$ & $\begin{array}{c}2.2523 \\
(0.5271) \\
492\end{array}$ & $\begin{array}{c}2.3138 \\
(0.4554) \\
387\end{array}$ & $\begin{array}{c}2.5349 \\
(0.4453) \\
312\end{array}$ \\
\hline
\end{tabular}

Notes: Proportions are reported for UNION and fringe benefits and means for the $\ln W A G E$. Standard errors are in parentheses. 
The "fringe benefit" variables are based on responses to the questions of whether or not the respondents' employer offers or makes available the particular benefit. Dummy variables are constructed such that they equal one if the respondent reported that his employer offered or provided the particular benefit. We focus on the following fringe benefits: medical, retirement, life insurance, and dental. As shown in Table 1, the proportion of workers reporting the availability of benefits increases by establishment size for all of the fringe benefits. The average of the natural log of wage also increased by establishment size. The proportion of workers belonging to a union increased over the first three size categories and was actually slightly lower (at 21 percent) in the fourth category than in the third category (at 23 percent). Our empirical specification is:

$$
\begin{aligned}
& P_{i}=\alpha+\beta_{S 2}(\text { SIZE2) })_{i}+\beta_{S 3}(\text { SIZE3) })_{i}+\beta_{S 4}(\text { SIZE4 })_{i}+\beta_{U 1}\left(U_{I}\right)_{i} \\
& +\beta_{U 2}\left(U_{2}\right)_{i}+\beta_{U 3}\left(U_{3}\right)_{i}+\beta_{U 4}\left(U_{4}\right)_{i}+\beta_{2}{\text { (Actual Experience })_{i}} \\
& +\beta_{3}\left(\text { Actual Experience }^{2}\right)_{i}+\beta_{4}(\text { Tenure })_{i}+\beta_{5}\left(\text { Tenure }^{2}\right)_{i} \\
& +\beta_{6}(\text { Education })_{i}+\beta_{7}(\text { AFQT })_{i}+\beta_{8}{\text { (Marital Status })_{i}} \\
& +\beta_{9}(\text { Urban })_{i}+\beta_{I 0}(\text { Number of Children })_{i}+\beta_{I I}\left(\text { Black }_{i}\right.
\end{aligned}
$$

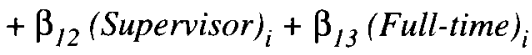

$$
\begin{aligned}
& + \text { (Vector of Regional Dummies) } \mu \\
& +(\text { Vector of Industrial Dummies }) \eta \\
& + \text { (Vector of Occupational Dummies) } \omega+\text { Error }_{i} \text {, }
\end{aligned}
$$

where $U$ is a vector of four union-establishment size interaction terms. $U_{I}$ equals 1 for union workers in the smallest establishment size and 0 otherwise; $U_{2}$ equals 1 for union workers in the second establishment size, and so on.

We estimate the above model for each of the fringe benefits by logistic regression techniques given our qualitative dependent variables (which equal 1 if a particular fringe is provided by the employer or 0 otherwise) for the entire sample. Insight into the impact of unions on the probability of being offered a fringe benefit is found by examining the coefficients on $U_{1}, U_{2}, U_{3}$, and $U_{4}\left(\beta_{U i}, i=1,2,3,4\right)$ in the above specification. Given the richness of the NLSY it is possible to construct a measure of work experience that represents actual weeks worked, less tenure at current firm. There are several reasons why a measure of actual experience is preferred to using potential work experience (usually defined as age - education - 6). Potential experience may understate the returns to experience because it treats time not working the same as time working. This is particularly troublesome when estimating wages of persons who are more likely to have intermittent labor force participation. ${ }^{2}$ The use of both actual experience and tenure at the current firm, and their squares, as control variables should capture the total work experience of the respondent.

There are several reasons to include the Armed Forces Qualifications Test as an independent variable in the model. First, it may proxy for unobserved ability (Blackburn and Neumark, 1992). Second, Maxwell (1994) has successfully argued that AFQT 
proxies for quality of schooling received. We include AFQT as an explanatory variable in addition to years of education. In this respect, we incorporate elements of both school quality and quantity.

Additionally, we include a vector of industry and occupation controls, which presumably capture much of the heterogeneity in monitoring technology not captured by establishment size. An additional variable that indicates if the worker supervises others is also included. Other variables include controls for marital status, full-time employment, actual number of children in the household, race, education level (as measured by number of years of schooling completed), region, and urban area.

The summary results of the logistic regressions focusing on only the union-size interaction term coefficients are presented in Table $2 .{ }^{3}$ Given our main interest of investigating union-nonunion benefit differentials across different plant sizes, we limit our discussion to the estimated union-size interaction term coefficients. We find a pattern of differentials for each of the benefits that is very similar to that found for wages by Podgursky (1986) and for health benefits found by Bramley et al. (1989). In particular, as reported in Panel A, the union-nonunion differentials are largest in small plants for medical, retirement, dental, and life insurance. In general, the estimated union-size coefficients get progressively smaller as establishment size increases. For medical the coefficients fall in magnitude from $U_{1}$ to $U_{4}$, and for retirement the coefficients fall from

Table 2

Summary of Regression Results: Union-Size Interaction Term Coefficient

\begin{tabular}{lcccc}
\hline & $U_{I}$ & $U_{2}$ & $U_{3}$ & $U_{4}$ \\
\hline A. Logistic & & & & \\
MEDICAL & 1.6279 & 0.8294 & 0.3650 & 0.0281 \\
& $(0.000)$ & $(0.103)$ & $(0.533)$ & $(0.974)$ \\
& {$[0.398]$} & {$[0.115]$} & {$[0.025]$} & {$[0.001]$} \\
RETIREMENT & 1.9658 & 1.9751 & 0.5480 & 0.1980 \\
& $(0.000)$ & $(0.000)$ & $(0.125)$ & $(0.711)$ \\
LIFE INSURANCE & {$[0.422]$} & {$[0.478]$} & {$[0.092]$} & {$[0.019]$} \\
& 0.8712 & 0.5406 & 0.6059 & 0.1327 \\
& $(0.009)$ & $(0.136)$ & $(0.138)$ & $(0.810)$ \\
DENTAL & {$[0.214]$} & {$[0.113]$} & {$[0.008]$} & {$[0.001]$} \\
& 1.4617 & 0.8755 & 0.2120 & 0.3014 \\
B. OLS & $(0.000)$ & $(0.004)$ & $(0.466)$ & $(0.493)$ \\
$\ln$ WAGE & {$[0.322]$} & {$[0.216]$} & {$[0.045]$} & {$[0.037]$} \\
& & & & \\
& & & & 0.1638 \\
& 0.2892 & 0.1761 & 0.1904 & $(0.004)$ \\
\hline
\end{tabular}

Note: $P>|z|$ in parentheses, and marginal probabilities are given in square brackets. 
$U_{2}$ to $U_{4}$. In the case of life insurance, the coefficient on $U_{3}$ is actually larger than the coefficient on $U_{2}$, though this difference is not large. For dental, the coefficient on $U_{4}$ is marginally larger than the coefficient on $U_{3}$. While the patterns for life insurance and dental are not as convincing as for medical and retirement, they do reveal similar patterns. Finally, as the OLS results reported in Panel B indicate, we actually find a narrowing union wage premium as we move from smaller establishment size to larger establishment size, with the exception that the coefficient on $U_{3}$ is slightly bigger than the coefficient on $U_{2}$. The general indication is that the impact of being a union worker is greatest in the smallest establishment. As shown by Podgursky (1986), our results indicate the union effect appears to shrink as establishment size increases.

Table 2 also presents information regarding the magnitude of the effect that belonging to a union has on the probability ${ }^{4}$ of being offered various fringe benefits evaluated at the mean for that establishment size. As establishment size increases the marginal effect of belonging to a union on receiving the benefit falls for all the fringe benefits studied. This is consistent with the phenomenon of observing larger unionnonunion differentials at smaller establishments.

\title{
IV. Concluding Remarks
}

We examined union-nonunion benefit differentials by establishment size. Several arguments indicate that we should observe larger union-nonunion benefit differentials in small plants. The majority of our findings support this hypothesis. We provide new empirical evidence on union-nonunion differentials using the NLSY data set which allowed us to examine a broader set of fringe benefits than most other studies, and provided a rich set of control variables. Our major finding is that the union effect decreases with establishment size for both components of the compensation structure, i.e., wages and fringe benefits.

\section{NOTES}

\begin{abstract}
*An earlier version of this paper was presented at the Southern Economic Association conference in Washington, DC in 1996. We thank Tom Hyclak and other session participants. We also acknowledge the financial support from Ade Howe Kent Fund. The usual disclaimer applies.

\footnotetext{
'Milkman and Mitchell (1995) developed a model in which the firm's choice of plant size depends on the probability of being unionized. Their results indicate that this effect may prevent firms from achieving all significant economies of scale.
}

\footnotetext{
${ }^{2}$ Stratton (1995) has examined the affect that timing of work interruptions may have on the degree of human capital depreciation.

${ }^{3}$ Full regression results available on request.

${ }^{4}$ The marginal probability is given by: $\delta P_{i} / \delta U_{j i}=\beta_{U i j} * P_{i}\left(1-P_{i}\right)$.
} 


\section{REFERENCES}

Blackburn, McKinley and David Neumark. "Unobserved Ability, Efficiency Wages, and Interindustry Wage Differentials." Quarterly Journal of Economics 107 (November 1992): 1421-36.

Bramley, Donald G., Phanindra V. Wunnava, and Michael D. Robinson. "A Note on Union-Nonunion Benefit Differentials and Size of Establishment." Economics Letters 30 (January 1989): 85-88.

Brown, Charles and James Medoff. "The Employer-Size Wage Effect." Journal of Political Economy 97 (October 1989): 1027-59.

Casey, Bernard. "Employers' Provision of Pensions and Sick Pay: Evidence from the 1990 Workplace Industrial Relations Survey." Applied Economics 26 (March 1994): 229-37.

Evans, David S. and Linda S. Leighton. "Why Do Smaller Firms Pay Less?" Journal of Human Resources 24 (Spring 1989): 299-318.

Even, William E. and David A. Macpherson. "The Gender Gap in Pensions and Wages." Review of Economics and Statistics 72 (May 1990): 259-65.

."Employer Size and Compensation: The Role of Worker Characteristics." Applied Economics 26 (September 1994): 897-907.

Freeman, Richard and James Medoff. "Substitution between Production Labor and Other Inputs in Unionized and Nonunionized Manufacturing." Review of Economics and Statistics 64 (May 1982): 220-33.

Jarrell, Stephen B. and T. D. Stanley. "A Meta-Analysis of the Union-Nonunion Wage Gap." Industrial and Labor Relations Review 44 (October 1990): 54-67.

Lindberg, Assar and Dennis J. Snower. "Efficiency Wages Versus Insiders and Outsiders." European Economic Review 31 (February-March 1987): 407-16.

Main, Bruce G. M. and Barry Reilly. "The Employer Size-Wage Gap: Evidence for Britain." Economica 60 (May 1993): 125-42.

Maxwell, Nan. "The Effect on Black-White Wage Differences of Differences in the Quantity and Quality of Education." Industrial and Labor Relations Review 47 (January 1994): 249-63.

Mellow, Wesley. "Employer Size and Wages." Review of Economics and Statistics 64 (August 1982): 341 -45.

Milkman, Martin and Merwin Mitchell. "Union Influence on Plant Size." Journal of Labor Research 16 (Summer 1995): 319-29.

Morissette, Rene. "Canadian Jobs and Firm Size: Do Smaller Firms Pay Less?" Canadian Journal of Economics 26 (February 1993): 159-74.

Oi, Walter Y. "Heterogeneous Firms and the Organization of Production." Economic Inquiry 21 (April 1983): $147-84$

"Heterogeneous Firms: Caveat Emptor." Economic Inquiry 25 (January 1987): 181-84.

"Employment Relations in Dual Labor Markets (It's Nice Work If You Can Get It)." Journal of Labor Economics 8 (January 1990): S124-S149.

Okunade, Albert A., Phanindra V. Wunnava, and Michael D. Robinson. "Union-Nonunion Differentials and Industry Structure." Economics Letters 39 (July 1992): 329-37.

Podgursky, Michael. "Unions, Establishment Size, and Intra-Industry Threat Effects." Industrial and Labor Relations Review 39 (January 1986): 277-84.

Robinson, Michael D. "Sex Discrimination in Non-Wage Compensation: Pension and Health Insurance Participation." Eastern Economic Journal 17 (October-December 1991): 463-68.

Stratton, Leslie. "The Effect Interruptions in Work Experience Have on Wages." Southern Economic Journal 61 (April 1995): 955-70.

Wiatrowski, William J. "Employee Benefits for Union and Nonunion Workers." Monthly Labor Review 117 (February 1994): 34-37. 